\title{
Aquadest production system as steam turbine bottom cycle II: influence of condenser pressure and pinch point temperature difference
}

\author{
$E A$ Kosasih ${ }^{l,}$,,$R I \mathrm{Wahid}^{l}$, and $A A$ Faros $^{l}$ \\ ${ }^{1}$ Departemen of Mechanical Engineering, University of Indonesia, Depok 16424, Indonesia
}

\begin{abstract}
Most of the energy derived from Steam turbine is discharge in the condenser at temperatures that may damage the environment. The condenser cooling water has gone through water treatment process, so it would be better used as raw material to produce aquadest. This study simulate a system that produces aquadest by throttling $10 \%$ of cooling water that coming out the condenser into a vacuum chamber $(3 \mathrm{kPa})$. The resulting cold vapoor is condensed in the evaporator become aquadest. Cold water coming out the vacuum chamber is mixed with water coming out the condenser is lower than before. Parameters that varied are the condenser pressure and pinch point temperature difference ( PPTD) inside the condenser. The simulation resulted the condenser cooling water temperature of less than $40^{\circ} \mathrm{C}$ (design point), especially at PPTD of 9 ${ }^{\mathrm{O}} \mathrm{C}$. that applicable to all variations of condenser pressure 7 to $12[\mathrm{kPa}$. Spesific energy consumption of aquadest are between 550,7 to 900,3 [ $\mathrm{kPa}$ ] (less than half of water evaporation heat) and the aquadest flowrate are between 0,116 to $0,319[\mathrm{~kg} / \mathrm{s}]$.
\end{abstract}

\section{Introduction}

Walter is an important environmental component for life. Creature life on earth cannot be separated from the need for air. Water is a major need for life's processes on earth. As we know that $97 \%$ of the water in the earth is sea water, desalination system is needed, that can change sea water with ready-to-use water. The current desalination technology can be classified as a single-phase process (e.g. reverse osmosis, electro dialysis) or, as a process of phase change (e.g. distillation, solar). Among other things, the reverse osmosis process, electro dialysis, and distillation require high quality motive energy derived from non-renewable fossil fuel sources. This technology contributes indirectly to greenhouse gas emissions and is not sustainable. While the sun is still driven by solar energy not suffering from this deficiency, they are geographically and technically limited to wider applications due to low efficiency, low yield, and batch operations. Development of clean technologies that use renewable energy to produce potable water can be a sustainable solution to the global problem of drinking water supplies.[1]

Scholars have done a lot of work on water purification and other aspects, but the principles of this method are not the same and new methods and new technologies are constantly emerging. For example, Surajbhan Sevda et al. Using microbial respiration to purify water, and they have made the volume of single seawater desalination space increased from $3 \mathrm{ml}$ to $15 \mathrm{~L}[2]$. There are also many traditional studies on distilled water by evaporative pipes, such as Ahmed Hegazy collecting water through a vacuum evaporator to condensation collecsteam, and energy consumption of about 1-8 kwh / kg [3]; Ebrahimi Khosrow studied the use of low-temperature heat sources for seawater desalination, etc. To follow up the efforts of the above researchers in producing desalination water[4]. On many occasions, researchers have also competed in developing SWRO (sea water reverse osmosis) technology to produce desalination water. Sarai athab et al utilized water from main outfall drain in iraq with reverse osmosis method and required a specific energy consumption of $2.8 \mathrm{kwh} / \mathrm{m} 3$ [5]. Thomas M. Missimer et al discusses the effect of SWRO placement on the environment[6]. F Munoz et al studied the use solar desalination at small capacity with SWRO[7]. A. Alzahrani et al studied Thermodynamic analysis of a reverse osmosis desalination unit with and without an energy recovery system, beside that for specific energy consumption for reverse osmosis may change depending on the configuration of the SWRO[8]. This paper describes the application of throttling process on cooling sea water condenser at power plant. By utilizing the wasted heat carried by cooling water out of condenser in Power Plant, we can produce aquadest.

\section{Literature Review}

\subsection{Throttling Process}

Throttling valve is a kind of device that causes a very significant pressure drop on the flow of fluid. Unlike turbine, throttling valve produces pressure drop without

\footnotetext{
* Corresponding author: kos.ri@gmail.com
} 
generating energy. The aappearance of pressure drop is often accompanied by decreases of temperature. This phenomenon throttling process is often used for refrigeration and air-conditioning applications. The use of throttling valve is usually for small scale, these results in a flow through the throttling valve assuming adiabatic $(q \equiv 0)$. In this paper will discuss application throttling process for large scale. In addition to throttling valve also does not occur the addition / reduction of energy and no potential energy change. Even so the flow velocity after passing throttling valve is higher than before passing throttling valve, but this difference is not very significant. To produce water aquadest, this pressure drop is play a role in lowering the saturated temperature of the flowing fluid. This causes water after passing throttling valve will partly be vapour. Then the vapours is cooled and accumulated into aquatic water. When the throttle valve is in the wide open mode, volumetric efficiency increases and, in turn, the in-cylinder pressure.[9] The use of throttling process is mostly used to condense the fluid. As has been done by some researchers such as Wang modelled condensate throttling system and designed a control strategy for $330 \mathrm{MW}$ coal-fired power plant.[10] Wang et al a model of condensate throttling in wide range operating conditions is presented, and a novel coordinate control is designed for improving flexibility of units.[11]

\subsection{Thermodynamics Simulation}

Thermodynamic simulation is a simulation that focuses on thermodynamic parameters at each point. Since the thermodynamic simulation reference is the point then in doing thermodynamic simulation there should be no equipment required. However, thermodynamic simulations are used as reference before designing. Thermodynamic simulation can describe the efficiency of a system and so forth. The development of this throttling process configuration utilizes the waste heat from outter cooling water condenser by throttling the cooling water out from condenser into the vacuum chamber. In thermodynamic simulation, we calculate aquadest production from spesific mass flowrate of working fluid in power plant.

Thermodynamic simulation aims to determine the good process conditions associated with the development of throttling process configuration on cooling water condenser as capable of producing aquadest, and reduce waste heat in condenser outter. In addition to the advantages that have been mentioned, there are consequences to apply it that requires electrical energy.

\subsection{Type of Fluids}

\subsubsection{Cooling Water}

To change the phase of the working fluid of the steam power plant from steam to fluid it is necessary that the fluid can absorb the heat from the working fluid so that the phase becomes liquid. Cooling water in PLTU can be taken from river, lake, sea water, etc. Cooling water is very that we will discuss here is cooling water taken from sea water. High cooling water inlet temperature (t1) leads to higher saturation temperature and corresponding rise in condenser saturation pressure (i.e. Lower condenser vacuum) for a design specified cooling water temperature rise and terminal temperature difference. These are two effects caused by the cooling water inlet temperature. The primary one is to alter the steam saturation temperature by the same amount as the change. Reduced cooling water flow shall increase the cooling water temperature rise, which leads to higher saturation temperature at design terminal temperature difference and corresponding saturation pressure. Cooling water pressure drop across the condenser tubes reduces the cooling water flow[9].

\subsubsection{Working Fluid}

Working fluid is a fluid used by a power plant to generate energy from the phase change occurring in the fluid. Working fluid will be pumped into the boiler, then enter into the boiler to be heated so that the phase becomes steam and high pressure, then enter the gas turbine to rotate the turbine and turbine will rotate generator that will generate electrical energy. After passing turbine then working fluid will change its phase become liquid and gas then get into condenser to be taken hot by cooling water so it is expected out of condenser of its phase become liquid. After that, the fluid goes into the pump to be sent back to the boiler.

\subsection{Pinch Point}

The pinch technology was proposed firstly for optimization of heat exchangers and therefore it is introduced / described below for such devises. The effect of the PPTD assignment on the system performance is investigated with optimization algorithm. The combined influence of economical and thermal performance are considered.[11]

\section{Proposed System}

From the figure 1 can be seen that the sea water coming out of water treatment mixed with water throttling valve. This is so that water results from water treatment can release heat to water throttling process results. So the mixed water entalpy becomes lower. This follows the following equation:

$$
h_{c 2}=\frac{m_{c 4} * h_{c 1}+P_{\text {Pump }}+m_{c 1} * h_{c 1}}{m_{c 2}}
$$

With hc2 lower than hc1 then the temperature will also be lower. Following the following equation:

$$
T_{c 2}=T(P, h)
$$

Before cooling water from water treatment and cooling water from vaccum chamber. To determine Pump power is:

$$
P_{\text {pump }}=m_{c 4} * B
$$

Cooling water entering the condenser will absorb latent heat from the working fluid of the power plant. The energy conversion equation is as follows: 


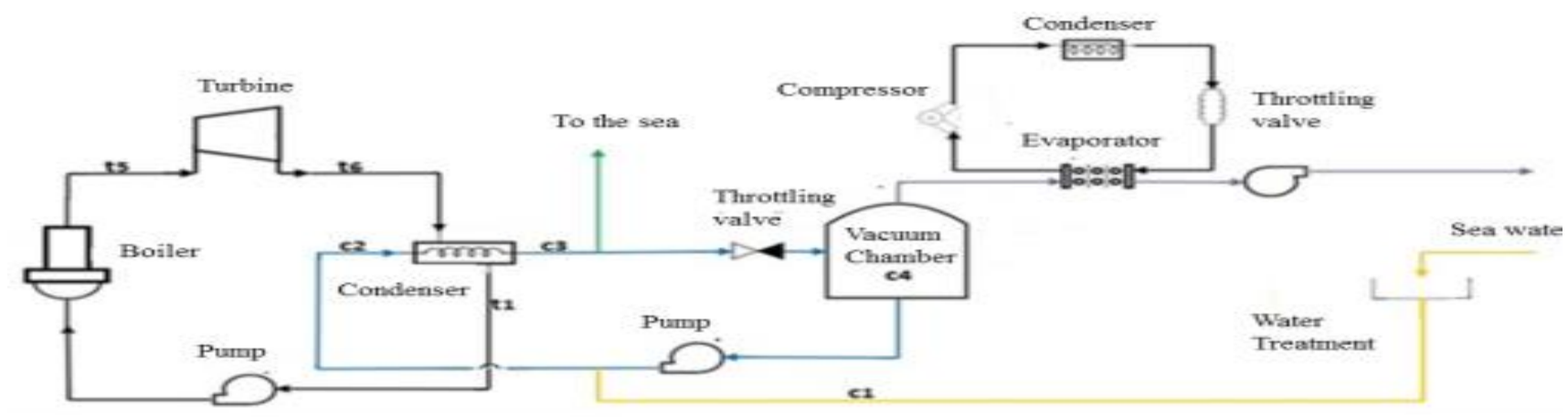

Fig. 1. Schematic Diagram of throttling process in sea water condenser power plant

$$
\begin{aligned}
& Q_{\text {condenser }}=\dot{m}_{w} *\left(h_{t 6}-h_{t 1}\right) \\
& Q_{\text {condenser }}=\dot{m}_{c w} *\left(h_{c 3}-h_{c 2}\right)
\end{aligned}
$$

By utilizing the wasted heat carried by cooling water out of condenser in Power Plant, we can produce distilled water. Basically the refrigeration system is a heat pump system, where heat/thermal energy is transferred, so get the effect of heating by the condenser unit[12]. To maximize the heat absorbed, the mass flow cooling water must be greater than the mass flow working fluid. To determine mass flow rate cooling water is:

$$
m_{c 2}=\frac{\dot{Q}_{\text {condenser }}}{C}
$$

Where konstanta $\mathrm{C}$ follow :

$$
C=h_{c 3}-A * h_{f c 4}-B-(1-A) * h_{c 1}
$$

Where $\mathrm{A}$ and $\mathrm{B}$ is konstanta

$$
\begin{gathered}
A=\frac{(1-\% m b)\left(h_{g c 4}-h_{c 3}\right)}{h_{f g c 4}} \\
B=V l_{c 4} *(101,325-3)
\end{gathered}
$$

Once out of the condenser, the entalpy working fluid will be lower than before entering the condenser and the entalpy cooling water will rise from before entering the condeser. The increase of enthalpy in cooling water also resulted in temperature increase in cooling water. The factors that influence the temperature rise of cooling water can also come from the pinch point of the condenser. This is in accordance with the following formula:

$$
T_{c 3}=T_{t 6}-P P T D
$$

PPTD value will allow us to determine the amount of expansion made by the turbine by looking at the temperature cooling water coming out of the condenser. The cooling water coming out of the partial condenser is discharged into the environment $(\mathrm{mb})$ and some will enter the throttling valve for the drain.

$$
\dot{m}_{b}=\% m_{b} * m_{c 2}
$$

The mass cooling water entering the throttling valve will be tied into the water tank and will produce vapoor.
Pressure in water tank in vacuum design, it will be produced water vapor following the following equation:

$$
\begin{gathered}
h_{c 4}=h_{c 3} \\
h_{c 4}=h_{f c 4}+\left(h_{h f c 4} * x\right) \\
\dot{m}_{\text {Aquades }}=x * \dot{m}_{c w 2}
\end{gathered}
$$

With the throttling process on cooling sea water condenser then we are able to increase the production of electricity that will be generated this is because the ability to condense heat dissipation will also increase. This corresponds to the following equation:

$$
\in=\frac{T_{t 1}-T_{t 6}}{T_{c 3}-T_{t 6}}
$$

Assuming $\mathrm{T}_{\mathrm{t} 1}$ and $\mathrm{T}_{\mathrm{t} 6}$ are constant and $\mathrm{T}_{\mathrm{c} 3}$ is lower than before then the value of $\in$ will increase. By using throttling process method in cooling water condenser at power plant then temperature cooling water into condesner will be cooler. So difference between temperature working fluid with cooling water temperature becomes larger. So the effectiveness of the condenser will increase. With the ability of condenser to release the heat increases the turbine power can change as needed. With the throttling process in the cooling water condenser at the power plant, there is a difference in the electric power generated by the steam turbine due to the decrease in enthalpy working fluid entering the condenser. Then the power changes follow the following formula:

$$
\Delta P=P_{\text {turbine baru }}-P_{\text {turbine lama }}
$$

After passing through the water spout, the heat at point c4 will be carried by water vapor, which water vapor will be condensed into aquadest by using refrijrasi system. The power required to condense water vapor is as follows:

$$
Q_{\text {evaporator }}=\dot{m}_{\text {uap air }} * h_{f g c 5}
$$

Power required is as follows:

$$
W_{\text {compresor }}=\frac{Q_{\text {evaporator }}}{\text { COP }}
$$


Once we know the power requirements used in the throttling process system on the cooling water condenser at the power plant, we can calculate the specific energy consumption to produce aquadest water, which is as follows:

$$
S E C=\frac{P_{\text {compressor }}+P_{\text {pompa }}-\Delta P_{\text {turbine }}}{\dot{m}_{\text {Aquades }}}
$$

Table 1. Boundary Condition of Simulation Thermodynamics

\begin{tabular}{|c|c|}
\hline Parameter & Value \\
\hline $\mathrm{P}_{\mathrm{t} 5}$ & $8900 \mathrm{kPa}$ \\
\hline $\mathrm{T}_{\mathrm{t} 5}$ & $510{ }^{0} \mathrm{C}$ \\
\hline $\mathrm{P}_{\mathrm{cl}}=\mathrm{P}_{\mathrm{c} 4}$ & $101,325 \mathrm{kPa}$ \\
\hline $\mathrm{T}_{\mathrm{c} 1}$ & $30{ }^{0} \mathrm{C}$ \\
\hline Vacuum chamber pressure & $3 \mathrm{kPa}$ \\
\hline COP & 3 \\
\hline $\begin{array}{c}\text { percentage mass flow cooling water } \\
\text { out to the sea }\end{array}$ & $90 \%$ \\
\hline Initial design condenser pressure & $12 \mathrm{kPa}$ \\
\hline Effisiensi isentropik turbine & $87 \%$ \\
\hline
\end{tabular}

\section{Result and Discussion}

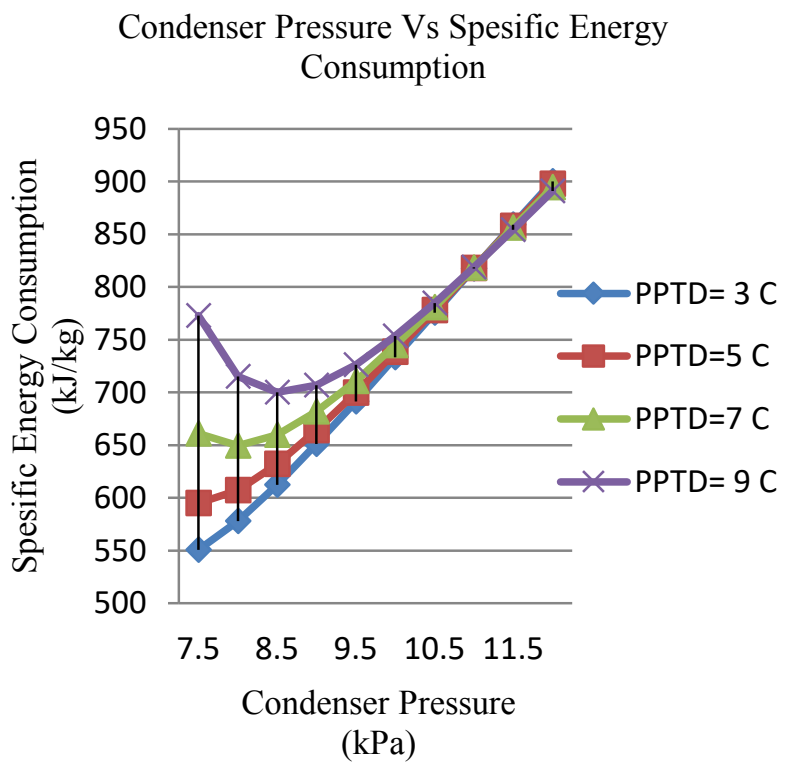

Fig. 2. Condenser Pressure Vs. Spesific Energy Consumption graph

From pinch point temperature different, we can know the temperature of cooling water coming out from condenser. With the rising temperature of cooling water it will affect the production of aquadest. The greater the pinch point value the production of the aquadest will decrease further. This is because the greater the pinch point of eating will be the greater the gap between the temperature saturated condenser with cooling water temperature out of the condenser. Assuming condenser vacuum pressure, we can see the phenomenon that occurs from the equation 9 .

A decrease in temperature will also have an impact with decreased enthalpyy. With the smaller enthalpy the aquadest production will also decrease. By reducing the production of the aquadest, it will increase the specific energy consumption. With a few aquadest producers and the same load of energy consumption will result in the SEC rising. It can be seen on the figure 2 that at certain pinch point and certain condenser vacuum pressure the aquadest production stalled. And onward there is water condensation instead of evaporating water.

On pinch point $3{ }^{\circ} \mathrm{C}$ and $5{ }^{\circ} \mathrm{C}$, the influence of condenser pressure on specific energy consumption is linear. On pinch point $7^{\mathrm{O}} \mathrm{C}$, the lowest specific energy consumption at $8 \mathrm{kpa}$ is $649.41 \mathrm{kj} / \mathrm{kg}$ ( $27 \% \mathrm{hfg}$ of water). After that the specific energy consumption at higher pressure will be increase. On pinch point $9{ }^{\circ} \mathrm{C}$, the lowest specific energy consumption at $8.5 \mathrm{kpa}$ pressure is 699.96 $\mathrm{kj} / \mathrm{kg}$ ( $29 \%$ hfg of water).

Condenser Pressure Vs Aquadest Production

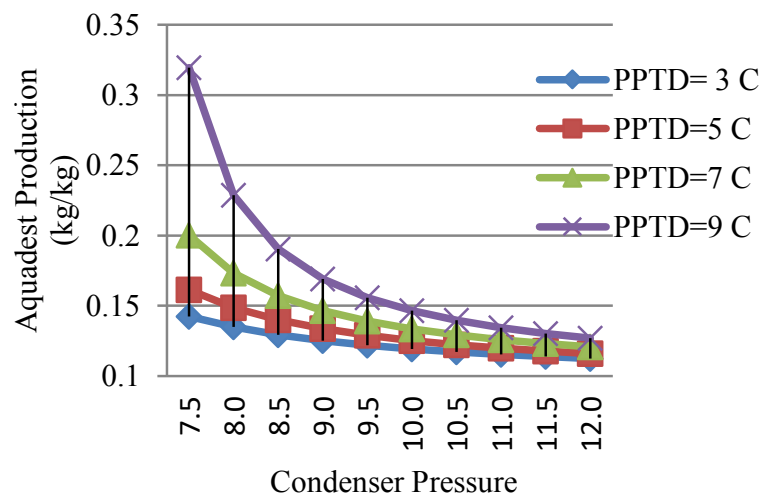

$(\mathrm{kPa})$

Fig. 3. Condenser Pressure Vs. Aquadest Production graph

Table 2. Aquadest production for each PPTD

\begin{tabular}{|c|r|r|r|r|}
\hline \multirow{2}{*}{$\begin{array}{l}\text { condenser } \\
\text { pressure }(\mathbf{k P a})\end{array}$} & \multicolumn{4}{|c|}{ PPTD $\left({ }^{\mathbf{O}} \mathbf{C}\right)$} \\
\cline { 2 - 5 } & $\mathbf{3}$ & $\mathbf{5}$ & $\mathbf{7}$ & $\mathbf{9}$ \\
\hline 7,50 & 0,14 & 0,16 & 0,20 & 0,31 \\
\hline 8,0 & 0,135 & 0,149 & 0,173 & 0,229 \\
\hline 8,5 & 0,129 & 0,140 & 0,157 & 0,190 \\
\hline 9,0 & 0,125 & 0,134 & 0,147 & 0,169 \\
\hline 9,5 & 0,122 & 0,129 & 0,139 & 0,156 \\
\hline 10,0 & 0,119 & 0,125 & 0,134 & 0,146 \\
\hline 10,5 & 0,117 & 0,122 & 0,129 & 0,140 \\
\hline 11,0 & 0,115 & 0,120 & 0,126 & 0,134 \\
\hline 11,5 & 0,114 & 0,118 & 0,123 & 0,130 \\
\hline 12,0 & 0,112 & 0,116 & 0,121 & 0,127 \\
\hline
\end{tabular}

Can be seen figure 3 the higher the condenser pressure to aquadest production will decrease further. Because the higher the condenser pressure so the mass flowrate 
cooling water into the condenser will be higher,so the difference temperature cooling water between coming in with the exit will be greater then the condenser capacity condenses the working fluid will be higher so that the mass flow rate cooling water becomes lower according to equation $4 \mathrm{~b}$. At the same condenser pressure codition, the higher the value of PPTD so the higher aquadest production. The highest aquadest production is at $7.5 \mathrm{kpa}$.

\section{Condenser Pressure Vs \% Power Usage}

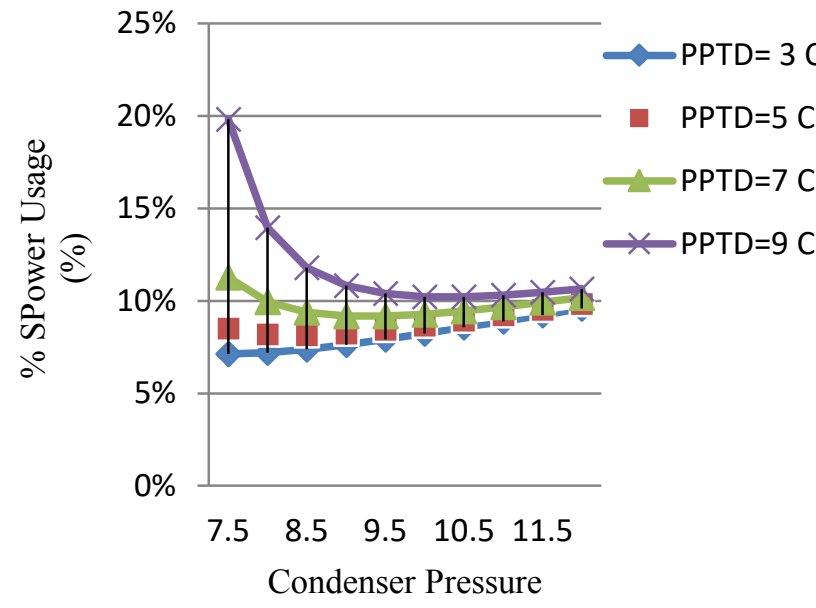

$(\mathrm{kPa})$

Fig. 4. Condenser Pressure Vs. power usage in power plant graph

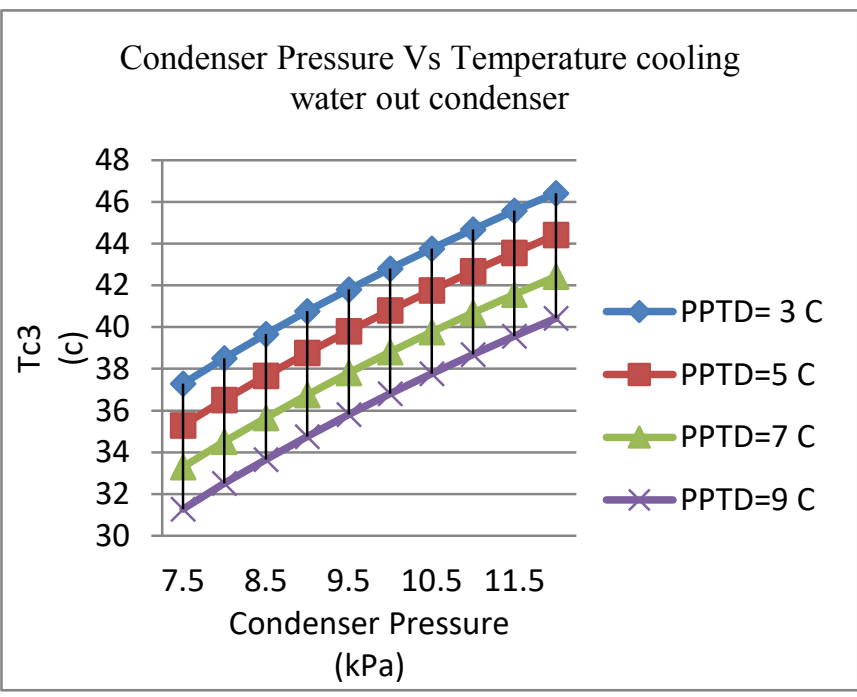

Fig. 5. Condenser Pressure Vs. Temperature cooling water out condenser graph

The electrical requirement to apply throttling process on cooling water condenser varies. Highest electricity requirement at condenser pressure $7,5 \mathrm{kpa}$ and PPTD $9{ }^{\circ} \mathrm{C}$, $20 \%$ of total power generated in power plant. While the lowest electricity power at condenser pressure 9-10 kpa and PPTD $3{ }^{\circ} \mathrm{C}$ is $8 \%$ of the total power generated in power plant. The lowest electricity requirement in PPTD $3 \mathrm{kpa}$ is $8 \%$ of the total power of the power plant. The lowest electricity requirement on PPTD ${ }^{\circ} \mathrm{C}$ is $8 \%$ of the total power of the power plant. The lowest electricity requirement on PPTD $7^{\circ} \mathrm{C}$ is $9 \%$ of the total power of the power plant. The lowest electricity requirement on PPTD $9{ }^{\circ} \mathrm{C}$ is $10 \%$ of the total power of the power plant.

After cooling water out of the condenser, the temperature cooling water discharged to the sea should be no more than $40^{\circ} \mathrm{C}$. Thermodynamics simulation results that have been done to get temperature cooling water out the lowest condenser is $31{ }^{\circ} \mathrm{C}$.

Table 3. Thermodynamics simulation result for Temperature cooling water out condenser

\begin{tabular}{|c|c|c|}
\hline $\begin{array}{c}\text { PPTD } \\
{ }^{\circ} \mathbf{C}\end{array}$ & $\begin{array}{c}\text { Condenser pressure } \\
\text { Kpa }\end{array}$ & $\begin{array}{c}\mathrm{Tc3} \\
{ }^{\circ} \mathbf{C}\end{array}$ \\
\hline 3 & 8,5 & 39,6 \\
\hline 5 & 9,5 & 39,8 \\
\hline 7 & 10,5 & 39,7 \\
\hline 9 & 11,5 & 39,5 \\
\hline
\end{tabular}

\section{Conclusion}

The results of the analytical for aquadest production system following conclusions: The feasibility of the proposed process configuration for aquadest production was demonstrated at thermodynamics simulation. Temperature of cooling water out from condenser for varied condenser pressure at $9{ }^{\circ} \mathrm{C}$. Minimum SEC for each PPTD $\left(3{ }^{\circ} \mathrm{C} ; 5{ }^{\circ} \mathrm{C} ; 7{ }^{\circ} \mathrm{C} ; 9^{\circ} \mathrm{C}\right)$ is $550,7 \mathrm{kj} / \mathrm{kg}(7,5$ $\mathrm{kpa}), 594,7 \mathrm{kj} / \mathrm{kg}(7,5 \mathrm{kpa}), 649,5 \mathrm{kj} / \mathrm{kg}$ (8kpa), 699,9 $\mathrm{kj} / \mathrm{kg}(8,5 \mathrm{kpa})$ To produce maximum aquadest is found in PPTD $=3{ }^{\circ} \mathrm{C}$, but temperature cooling water out from condenser is high. Temperature cooling water is safely dumped into the sea is at PPTD $=9{ }^{\circ} \mathrm{C}$.At $12 \mathrm{kPa}$ condenser pressure, temperature cooling water out the condenser is $40.4{ }^{\mathrm{O}} \mathrm{C}$. For obtaining reasonably high produced aquadest flowrate $(0,116-0,319 \mathrm{~kg} / \mathrm{s})$ at reasonably low specific energy consumption $(550,7-900,3$ $\mathrm{kj} / \mathrm{kg})$.

The author would like to thank Universitas Indonesia with the financial support through the PITTA 2018 funding schame managed by the Directorate for Research and Public Service (DRPM) Universitas Indonesia under contract No. 2429/UN2.R3.1/HKP.05.00/2018

\section{Nomenclature}

\begin{tabular}{|c|c|c|}
\hline COP & Coefficient of Performance & \\
\hline $\mathrm{h}$ & spesific enthalpy & {$[\mathrm{kg} / \mathrm{kg}]$} \\
\hline$\dot{m}$ & mass flowrate & {$[\mathrm{kg} / \mathrm{s}]$} \\
\hline $\mathrm{p}$ & Pressure & {$[\mathrm{kPa}]$} \\
\hline $\begin{array}{c}\text { PPT } \\
\text { D }\end{array}$ & Pinch Point Temperature & {$\left[{ }^{\mathrm{O}} \mathrm{C}\right]$} \\
\hline $\mathrm{Q}$ & Different & {$[\mathrm{kJ}]$} \\
\hline $\mathrm{s}$ & Heat & {$\left[\mathrm{kJ} / \mathrm{kg}^{\mathrm{O}} \mathrm{C}\right.$} \\
] & spesific entropy & {$[\mathrm{kJ} / \mathrm{kg}]$} \\
\hline SEC & Spesific Energy Consumption &
\end{tabular}




\begin{tabular}{|c|c|c|}
\hline COP & Coefficient of Performance & \\
\hline $\mathrm{T}$ & Temperatur & {$\left[{ }^{\circ} \mathrm{C}\right]$} \\
\hline $\mathrm{Vl}$ & Volume Spesifik & {$\left[\mathrm{m}^{3} / \mathrm{kg}\right]$} \\
\hline $\mathrm{x}$ & vapoor quality & {$[\%]$} \\
\hline
\end{tabular}

THERMODYNAMIC SYSTEM. International Journal of Technology, 2016.2:p.288-295

\section{References}

1. Gude, V.G. and N. Nirmalakhandan, Desalination at low temperatures and low pressures. Desalination, 2009. 244(1): p. 239-247.

2. Sevda, S., et al., Microbial desalination cells as a versatile technology: Functions, optimization and prospective. Desalination, 2015. 371: p. 9-17.

3. Hegazy, A., M. Hegazy, and A. Engeda, A novel desalination system for utilizing waste heat contained in cooling salt water of a steam plant condenser. Desalination, 2015. 371: p. 58-66.

4. Ebrahimi, K., G.F. Jones, and A.S. Fleischer, $A$ review of data center cooling technology, operating conditions and the corresponding low-grade waste heat recovery opportunities. Renewable and Sustainable Energy Reviews, 2014. 31: p. 622-638.

5. Sarai Atab, M., A.J. Smallbone, and A.P. Roskilly, An operational and economic study of a reverse osmosis desalination system for potable water and land irrigation. Desalination, 2016. 397: p. 174-184.

6. Missimer, T.M. and R.G. Maliva, Environmental issues in seawater reverse osmosis desalination: Intakes and outfalls. Desalination, 2018. 434: p. 198-215.

7. Muñoz, F. and L.A. Becerril, Low-capacity Reverse Osmosis Solar Desalination Plant. Energy Procedia, 2014. 57: p. 2787-2793.

8. Wang, W., et al., Modeling for condensate throttling and its application on the flexible load control of power plants. Applied Thermal Engineering, 2016. 95: p. 303-310.

9. Singh, S.P., G. Philip, and S.K. Singh, Effect of condenser vacuum on performance of a Reheat Regenerative $210 \mathrm{MW}$ Fossil-Fuel based Power Plants. International Journal of Emerging Technology and Advanced Engineering, 2014. 4: p. 190-195.

10. Rostami, S., et al., The effect of throttle valve positions on thermodynamic second law efficiency and availability of SI engine using bioethanolgasoline blends. Renewable Energy, 2017. 103: p. 208-216.

11. Wang, J., M. Diao, and K. Yue, Optimization on pinch point temperature difference of ORC system based on AHP-Entropy method. Energy, 2017. 141: p. 97-107.

12. Kosasih,A. E, and Ruhiyat Nanang, COMBINATION OF ELECTRIC AIR HEATER AND REFRIGERATION SYSTEM TO REDUCE ENERGY CONSUMPTION: A SIMULATION OF 